\title{
Działania opiekuńcze i terapeutyczne pielęgniarki w opiece nad dzieckiem z chorobą Leśniowskiego-Crohna w okresie jej zaostrzenia
}

\author{
Nursing and therapeutic activities of a nurse in caring for a child with \\ Crohn's disease during its exacerbation
}

\section{KASANDRA SZKLARCZYK ${ }^{1}$}

1 Studenckie Koło Naukowe Nauk o Zdrowiu, Instytut Nauk o Zdrowiu PUZ we Włocławku Opiekun Koła: dr Beata Haor

\section{Streszczenie}

Wstęp. Choroba Leśniowskiego-Crohna jest chorobą zapalną jelit o nieznanej etiologii. Rozpoznana zostaje najczęściej u dzieci oraz nastolatków. Do objawów charakterystycznych dla choroby należą bóle brzucha, oddawanie biegunkowych stolców często z obecnością patologicznych domieszek: krwi, ropy czy śluzu, a także ubytek masy ciała. Podstawowym krokiem w procesie terapeutycznym jest nawodnienie dziecka drogą dożylną lub doustną, włączenie farmakoterapii oraz leczenia żywieniowego. Celem wdrożonej terapii jest utrzymanie pacjenta w jak najdłużej trwającej remisji.

Cel. Praca ma na celu ukazać problemy opiekuńcze oraz terapeutyczne u dziecka z zaostrzeniem choroby Leśniowskiego-Crohna w warunkach szpitalnych oraz zadania personelu pielęgniarskiego wobec tego pacjenta.

Prezentacja przypadku. Pacjentka lat $15 \mathrm{w}$ drugiej dobie hospitalizacji przyjęta w oddział z podejrzeniem zaostrzenia choroby Leśniowskiego-Crohna. Pacjentka zgłasza liczne biegunki (od 10 do 15 wypróżnień na dobę) oraz ból brzucha. Przy przyjęciu temperatura ciała pacjentki wynosiła $38,4^{\circ} \mathrm{C}$. Dziewczyna oraz jej rodzice wykazują deficyt wiedzy na temat choroby oraz postępowania w przypadku jej zaostrzenia. 
Wnioski. Bardzo ważnym aspektem w leczeniu choroby Leśniowskiego-Crohna u opisanej pacjentki jest stosowanie się do zaleceń żywieniowych oraz systematyczne przyjmowanie zleconych środków farmakologicznych. Całkowite wyleczenie choroby nie jest możliwe, lecz podjęte działania w walce z chorobą pozwalają na uzyskanie długiej remisji i zmniejszenie ryzyka wystąpienia jej poważnych powikłań.

Słowa kluczowe: opieka pielęgniarska, nieswoiste zapalenia jelit, choroba Leśniowskiego-Crohna, leczenie, dziecko

\begin{abstract}
Introduction. Crohn's disease is an inflammatory bowel disease of unknown etiology. It is most often diagnosed in children and adolescents. The symptoms characteristic of the disease include abdominal pain, passing diarrheal stools, often with the presence of pathological admixtures: blood, pus or mucus and weight loss. The basic step in the therapeutic process is the intravenous or oral rehydration of the child, pharmacotherapy and nutritional treatment. The aim of the implemented therapy is to keep the patient in remission that lasts as long as possible.

The aim. The aim of the work is to show the care and therapeutic problems of a child with exacerbation of Crohn's disease in hospital conditions and the nursing staff towards the patient.

Case presentation. A 15-year-old patient on the second day of hospitalization was admitted to the ward with suspected exacerbation of Crohn's disease. The patient reports numerous diarrhea (from 10 to 15 bowel movements a day) and abdominal pain. On admission, the patient's body temperature was 38.4 ${ }^{\circ} \mathrm{C}$. The girl and her parents show a lack of knowledge about the disease and what to do in case of exacerbation.

Conclusion. A very important aspect in the treatment of Crohn's disease in the described patient is compliance with dietary recommendations and systematic use of prescribed pharmacological agents. It is not possible to cure the disease completely, but the measures taken to combat the disease allow for long remission and reduce the risk of its serious complications.
\end{abstract}

Keywords: nursing care, inflammatory bowel disease, Crohn's disease, treatment, child 


\section{Wstęp}

Choroba Leśniowskiego-Crohna należy do grupy nieswoistych chorób zapalnych jelit o nieznanej etiologii. Najczęściej rozpoznawana jest ona u nastolatków i młodzieży i w tym wieku ma tendencję do znacznie cięższego przebiegu, często skutkując powikłaniami, takimi jak przetoki czy zwężenia. U młodych ludzi choroba jest zwykle również bardziej rozległa, często obejmuje wiele miejsc $w$ jelicie grubym, z większą częstością zajęcia górnego odcinka przewodu pokarmowego. Ważnym aspektem choroby Leśniowskiego-Crohna u nastolatków i młodzieży jest wpływ choroby na ich życie codzienne, problemy związane $\mathrm{z}$ akceptacją przez nich wszystkich medycznych, psychologicznych i społecznych obciążeń, jakie niesie ze sobą ta poważna, destrukcyjna i przewlekła choroba $[1,2]$.

\section{Cel}

Celem poniższej pracy było przedstawienie planu opieki pielęgniarskiej w opiece nad dzieckiem z chorobą Leśniowskiego-Crohna w okresie jej zaostrzenia z wykorzystaniem Międzynarodowej Klasyfikacji Praktyki Pielęgniarskiej.

\section{Prezentacja przypadku}

Pacjentka, lat 15 przyjęta w oddział pediatrii w stanie ogólnym średnim w pierwszej dobie hospitalizacji z powodu zaostrzenia choroby Leśniowskiego-Crohna. U dziewczyny zaobserwowano temperaturę $38,4^{\circ} \mathrm{C}$ oraz cechy odwodnienia. Pacjentka oddaje liczne stolce (10-15 wypróżnień na dobę) o luźnej konsystencji, niekiedy z domieszką krwi oraz śluzu. Chora skarży się na dość silne bóle brzucha. Pacjentka wykazuje ogólny niepokój oraz zmęczenie.

W wywiadzie od października ubiegłego roku nawracające incydenty biegunek (w tym nocne defekacje), istotny ubytek masy ciała oraz niedokrwistość. Rozpoznanie choroby Leśniowskiego-Crohna postawiono w listopadzie 2019 r. Włączono wtedy leczenie glikokortyko- 
steroidami oraz antybiotykoterapię. Poza okresem stawiania diagnozy pacjentka w przeszłości nie była hospitalizowana.

Pacjentka żyje w pełnej rodzinie. Mieszka wraz z opiekunami prawnymi, którymi są jej rodzice biologiczni oraz dwiema młodszymi siostrami (10 i 12 lat). Warunki mieszkaniowe dobre, każde z dzieci ma swój własny pokój. Rodzice dziewczyny są zaniepokojeni stanem zdrowia córki. Wykazują deficyt wiedzy na temat choroby Leśniowskiego-Crohna oraz postępowania w okresie jej zaostrzenia.

Poniżej ukazano propozycję planu opieki nad dzieckiem z chorobą Leśniowskiego - Crohna w stanie zaostrzenia z wykorzystaniem klasyfikacji ICNP®, wersja z 2019 roku [3, 4].

\begin{tabular}{|c|c|c|c|c|}
\hline $\begin{array}{l}\text { Problem } \\
\text { pielęgna- } \\
\text { cyjny }\end{array}$ & $\begin{array}{l}\text { Cel plano- } \\
\text { wanych } \\
\text { działań } \\
\text { pielę- } \\
\text { gniar- } \\
\text { skich }\end{array}$ & $\begin{array}{l}\text { Planowane } \\
\text { interwencje } \\
\text { pielęgniarskie }\end{array}$ & $\begin{array}{l}\text { Uzasadnienie plano- } \\
\text { wanej interwencji } \\
\text { pielęgniarskiej }\end{array}$ & $\begin{array}{l}\text { Ocena } \\
\text { realizo- } \\
\text { wanych } \\
\text { działań } \\
\text { pielę- } \\
\text { gniar- } \\
\text { skich } \\
\end{array}$ \\
\hline $\begin{array}{l}\text { Zabu- } \\
\text { rzenia } \\
\text { gospodar- } \\
\text { ki wod- } \\
\text { no-elek- } \\
\text { trolitowej } \\
\text { spowo- } \\
\text { dowane } \\
\text { licznymi } \\
\text { biegunka- } \\
\text { mi }\end{array}$ & $\begin{array}{l}\text { Uzyskanie } \\
\text { prawi- } \\
\text { dłowej } \\
\text { gospodar- } \\
\text { ki wodno- } \\
\text {-elektroli- } \\
\text { towej }\end{array}$ & $\begin{array}{l}\text { - Zebranie } \\
\text { wywiadu na } \\
\text { temat liczby } \\
\text { i konsystencji } \\
\text { wypróżnień. } \\
\text { - Systematyczna } \\
\text { kontrola stanu } \\
\text { nawodnienia: } \\
\text { elastyczności } \\
\text { i koloru skóry, } \\
\text { nawilżenia błon } \\
\text { śluzowych, } \\
\text { ucieplenia dy- } \\
\text { stalnych części } \\
\text { kończyn, diurezy. }\end{array}$ & \begin{tabular}{|l|} 
Przeprowadzenie \\
wywiadu pomoże \\
w ocenie nasilenia \\
oraz ustalenia przy- \\
czyn biegunki. \\
Odwodnienie izoto- \\
niczne, które powstaje \\
na skutek występowa- \\
nia biegunek objawia \\
się cechami oligowo- \\
lemii, na skutek czego \\
konieczne jest wdro- \\
żenie terapii płynami \\
wieloelektrolitowymi \\
i chlorkiem sodu.
\end{tabular} & $\begin{array}{l}\text { Prawi- } \\
\text { dłowa go- } \\
\text { spodarka } \\
\text { wodno- } \\
\text {-elektro- } \\
\text { litowa } \\
\text { została } \\
\text { uzyskana }\end{array}$ \\
\hline
\end{tabular}




\begin{tabular}{|c|c|c|c|}
\hline & \begin{tabular}{|l|} 
- Pomiar podsta- \\
wowych parame- \\
trów życiowych \\
pacjentki. \\
- Założenie i pro- \\
wadzenie karty \\
bilansu płynów. \\
- Systematyczna \\
kontrola masy \\
ciała. \\
- Włączenie \\
kroplowych \\
wlewów dożyl- \\
nych na zlecenie \\
lekarza. \\
- Włączenie le- \\
ków przeciwbie- \\
gunkowych na \\
zlecenie lekarza. \\
• Polecenie spo- \\
żywania dużej \\
ilości płynów. \\
• Ocena skutecz- \\
ności podjętych \\
działań. \\
\end{tabular} & \multirow[t]{3}{*}{$\begin{array}{l}\text { Obserwowanie i doku- } \\
\text { mentowanie częstości } \\
\text { i charakteru wypróż- } \\
\text { nień pozwala na ocenę } \\
\text { reakcji na zastosowa- } \\
\text { ne leczenie. } \\
\text { Monitorowanie terapii } \\
\text { wodno - elektro- } \\
\text { litowej umożliwia } \\
\text { określenie stanu } \\
\text { nawodnienia dziecka } \\
\text { oraz odpowiedzi na } \\
\text { nawadnianie [5]. }\end{array}$} & \\
\hline $\begin{array}{l}\text { Diagnoza } \\
\text { negatyw- } \\
\text { na (kod } \\
\text { ICNP) }\end{array}$ & $\begin{array}{l}\text { Interwencje } \\
\text { pielęgniarskie }\end{array}$ & & $\begin{array}{l}\text { Diagnoza } \\
\text { pozytyw- } \\
\text { na (kod } \\
\text { ICNP) } \\
\end{array}$ \\
\hline $\begin{array}{l}\text { Brak rów- } \\
\text { nowagi } \\
\text { elektroli- } \\
\text { towej } \\
{[10033541]}\end{array}$ & \begin{tabular}{|l|} 
Planowanie opieki \\
{$[10035915]$} \\
Ocenianie statusu wypróż- \\
nienia $[10036475]$ \\
Ocenianie konsystencji stolca \\
{$[10030558]$} \\
Monitorowanie perystaltyki \\
jelit $[10037211]$ \\
Ocena integralności skóry \\
{$[10033922]$}
\end{tabular} & & $\begin{array}{l}\text { Prawidło- } \\
\text { wa rów- } \\
\text { nowaga } \\
\text { elektro- } \\
\text { litowa } \\
{[10033709]}\end{array}$ \\
\hline
\end{tabular}




\begin{tabular}{|l|l|} 
Monitorowanie oznak życia \\
{$[10032113]$} \\
Monitorowanie masy ciała \\
{$[10032121]$} \\
Administrowanie lekiem \\
i roztworem [10001804] \\
Współdziałanie w terapii \\
elektrolitami [10030948] \\
Współdziałanie w terapii \\
płynami [10030930] \\
Dokumentowanie \\
[10006173]
\end{tabular} \mid

\begin{tabular}{|c|c|c|c|c|}
\hline $\begin{array}{l}\text { Problem } \\
\text { pielęgna- } \\
\text { cyjny }\end{array}$ & \begin{tabular}{|l|} 
Cel plano- \\
wanych \\
działań \\
pielę- \\
gniar- \\
skich
\end{tabular} & $\begin{array}{l}\text { Planowane } \\
\text { interwencje } \\
\text { pielęgniarskie }\end{array}$ & $\begin{array}{l}\text { Uzasadnienie plano- } \\
\text { wanej interwencji } \\
\text { pielęgniarskiej }\end{array}$ & \begin{tabular}{|l|} 
Ocena \\
realizo- \\
wanych \\
działań \\
pielę- \\
gniar- \\
skich \\
\end{tabular} \\
\hline $\begin{array}{l}\text { Dyskom- } \\
\text { fort spo- } \\
\text { wodowa- } \\
\text { ny bólem } \\
\text { brzucha. }\end{array}$ & $\begin{array}{l}\text { Poprawa } \\
\text { samopo- } \\
\text { czucia } \\
\text { dziecka, } \\
\text { wyelimi- } \\
\text { nowanie } \\
\text { bólu. }\end{array}$ & $\begin{array}{l}\text { • Ocena stopnia } \\
\text { natężenia bólu } \\
\text { według skali } \\
\text { VAS. } \\
\text { - Polecenie uło- } \\
\text { żenia się w pozy- } \\
\text { cji zmniejszającej } \\
\text { napięcie mięśni } \\
\text { brzucha: zgięcie } \\
\text { kończyn dol- } \\
\text { nych w stawach } \\
\text { biodrowych } \\
\text { i kolanowych. } \\
\text { - Założenie i pro- } \\
\text { wadzenie karty } \\
\text { obserwacji bólu. }\end{array}$ & $\begin{array}{l}\text { Ocena stopnia nasile- } \\
\text { nia bólu pozwoliła na } \\
\text { prawidłowy dobór in- } \\
\text { terwencji pielęgniar- } \\
\text { skich. Wyjaśnienie } \\
\text { przyczyn dolegliwości } \\
\text { bólowych było czyn- } \\
\text { nikiem pozwalającym } \\
\text { na włączenie pacjent- } \\
\text { ki do współpracy. } \\
\text { Zgięcie kończyn w sta- } \\
\text { wach kolanowych } \\
\text { i biodrowych zmniej- } \\
\text { szyło napięcie mięśni } \\
\text { brzucha, co złagodziło } \\
\text { dolegliwości bólowe. }\end{array}$ & $\begin{array}{l}\text { Samo- } \\
\text { poczucie } \\
\text { dziecka } \\
\text { uległo } \\
\text { poprawie, } \\
\text { ból został } \\
\text { wyelimi- } \\
\text { nowany. }\end{array}$ \\
\hline
\end{tabular}




\begin{tabular}{|c|c|c|c|}
\hline & $\begin{array}{l}\text { - Podanie leków } \\
\text { przeciwbólo- } \\
\text { wych na zlecenie } \\
\text { lekarza. } \\
\text { • Wyjaśnienie } \\
\text { przyczyny bólu } \\
\text { oraz celowości } \\
\text { podawania środ- } \\
\text { ków przeciwbó- } \\
\text { lowych. } \\
\text { - Zalecenie od- } \\
\text { poczynku. } \\
\text { • Zapewnienie } \\
\text { ciszy i spokoju } \\
\text { oraz warunków } \\
\text { do snu. } \\
\text { - Pomaganie } \\
\text { w czynnościach } \\
\text { codziennych } \\
\text { w przypadku } \\
\text { silnych dolegli- } \\
\text { wości bólowych. } \\
\text { • Zastosowanie } \\
\text { technik relaksa- } \\
\text { cyjnych. } \\
\text { • Ocena skutecz- } \\
\text { ności podjętych } \\
\text { działań. } \\
\end{array}$ & \multirow[t]{3}{*}{$\begin{array}{l}\text { Prawidłowe zasto- } \\
\text { sowanie środków } \\
\text { przeciwbólowych } \\
\text { uśmierzyło ból. } \\
\text { Monitorowanie do- } \\
\text { znań bólowych oraz } \\
\text { założenie karty obser- } \\
\text { wacji bólu umożliwiło } \\
\text { oraz ocenę efektywno- } \\
\text { ści leczenia [5]. }\end{array}$} & \\
\hline $\begin{array}{l}\text { Diagnoza } \\
\text { negatyw- } \\
\text { na (kod } \\
\text { ICNP) }\end{array}$ & $\begin{array}{l}\text { Interwencje } \\
\text { pielęgniarskie }\end{array}$ & & $\begin{array}{l}\text { Diagnoza } \\
\text { pozytyw- } \\
\text { na (kod } \\
\text { ICNP) } \\
\end{array}$ \\
\hline $\begin{array}{l}\text { Ból } \\
\text { brzucha } \\
{[10043953]}\end{array}$ & $\begin{array}{l}\text { Planowanie opieki } \\
\text { [10035915] } \\
\text { Ocenianie bólu [10026119] } \\
\text { Monitorowanie bólu } \\
\text { [10038929] } \\
\text { Identyfikowanie postawy } \\
\text { wobec bólu [10009654] }\end{array}$ & & $\begin{array}{l}\text { Bez bólu } \\
{[10029008]}\end{array}$ \\
\hline
\end{tabular}


Administrowanie lekiem

[10025444]

Zarządzanie bólem

[10011660]

Zachęcanie do odpoczynku

[10041415]

Asystowanie w samoopiece

[10035763]

Nauczanie techniki relaksa-

cyjnej [10038699]

Ewaluacja odpowiedzi na za-

rządzanie bólem [10034053]

Dokumentowanie

[10006173]

\begin{tabular}{|c|c|c|c|c|}
\hline $\begin{array}{l}\text { Problem } \\
\text { pielęgna- } \\
\text { cyjny }\end{array}$ & $\begin{array}{l}\text { Cel plano- } \\
\text { wanych } \\
\text { działań } \\
\text { pielę- } \\
\text { gniar- } \\
\text { skich }\end{array}$ & $\begin{array}{l}\text { Planowane } \\
\text { interwencje } \\
\text { pielęgniarskie }\end{array}$ & $\begin{array}{l}\text { Uzasadnienie plano- } \\
\text { wanej interwencji } \\
\text { pielęgniarskiej }\end{array}$ & \begin{tabular}{|l|} 
Ocena \\
realizo- \\
wanych \\
działań \\
pielę- \\
gniar- \\
skich
\end{tabular} \\
\hline $\begin{array}{l}\text { Ryzyko } \\
\text { wystą- } \\
\text { pienia } \\
\text { powikłań } \\
\text { spowo- } \\
\text { dowane } \\
\text { wysoką } \\
\text { gorączką }\end{array}$ & $\begin{array}{l}\text { Obniżenie } \\
\text { tempe- } \\
\text { ratury } \\
\text { ciała do } \\
\text { wartości } \\
\text { prawi- } \\
\text { dłowych, } \\
\text { wyelimi- } \\
\text { nowanie } \\
\text { ryzyka } \\
\text { wystą- } \\
\text { pienia } \\
\text { powikłań }\end{array}$ & $\begin{array}{l}\text { - Systematyczny } \\
\text { pomiar tempe- } \\
\text { ratury ciała (co } \\
\text { godzinę lub w ra- } \\
\text { zie potrzeby). } \\
\text { - Interpretacja } \\
\text { i dokumento- } \\
\text { wanie wyników } \\
\text { uzyskanych } \\
\text { pomiarów. } \\
\text { - Zastosowanie } \\
\text { środków prze- } \\
\text { ciwgorączko- } \\
\text { wych na zlecenie } \\
\text { lekarza. }\end{array}$ & $\begin{array}{l}\text { Zastosowane leki oraz } \\
\text { zimne okłady skutecz- } \\
\text { nie obniżają tempera- } \\
\text { turę ciała dziecka. } \\
\text { Częsta zmiana bielizny } \\
\text { pościelowej i osobistej } \\
\text { jest konieczna z po- } \\
\text { wodu intensywnego } \\
\text { pocenia się dziewczyn- } \\
\text { ki. Mokra bielizna potę- } \\
\text { guje dreszcze i zwięk- } \\
\text { sza poczucie zimna. } \\
\text { Systematyczny pomiar } \\
\text { ciepłoty ciała pozwala } \\
\text { na ocenę skuteczności } \\
\text { podjętych działań [5]. }\end{array}$ & $\begin{array}{l}\text { Tempera- } \\
\text { tura ciała } \\
\text { dziecka } \\
\text { uległa } \\
\text { zmniej- } \\
\text { szeniu, } \\
\text { nie } \\
\text { doszło do } \\
\text { wystą- } \\
\text { pienia } \\
\text { powikłań } \\
\text { spowodo- } \\
\text { wanych } \\
\text { wysoką } \\
\text { gorączką. }\end{array}$ \\
\hline
\end{tabular}




\begin{tabular}{|c|c|}
\hline & $\begin{array}{l}\text { • Zastosowanie } \\
\text { okładów chło- } \\
\text { dzących na kark, } \\
\text { pachy i pachwiny } \\
\text { • Polecenie spo- } \\
\text { żywania dużej } \\
\text { ilości płynów. } \\
\text { - Częsta zmiana } \\
\text { bielizny poście- } \\
\text { lowej pacjentki, } \\
\text { pomoc w zmia- } \\
\text { nie bielizny } \\
\text { osobistej. } \\
\text { - Zapewnienie } \\
\text { odpowiedniego } \\
\text { mikroklimatu } \\
\text { na sali pacjentki } \\
\text { (wilgotność na } \\
\text { poziomie 40-70\%, } \\
\text { temperatura } \\
\text { 19-22C). } \\
\text { - Ocena skutecz- } \\
\text { ności podjętych } \\
\text { działań. }\end{array}$ \\
\hline $\begin{array}{l}\text { Diagnoza } \\
\text { negatyw- } \\
\text { na (kod } \\
\text { ICNP) }\end{array}$ & $\begin{array}{l}\text { Interwencje } \\
\text { pielęgniarskie }\end{array}$ \\
\hline $\begin{array}{l}\text { Gorączka } \\
\text { [10041539] }\end{array}$ & $\begin{array}{l}\text { Planowanie opieki } \\
\text { [10035915] } \\
\text { Zmierzenie temperatury } \\
\text { ciała [10032006] } \\
\text { Monitorowanie temperatury } \\
\text { ciała [10012165] } \\
\text { Administrowanie lekiem } \\
\text { przeciwgorączkowym } \\
\text { [10037248] } \\
\text { Zastosowanie okładu chło- } \\
\text { dzącego [10036468] }\end{array}$ \\
\hline
\end{tabular}

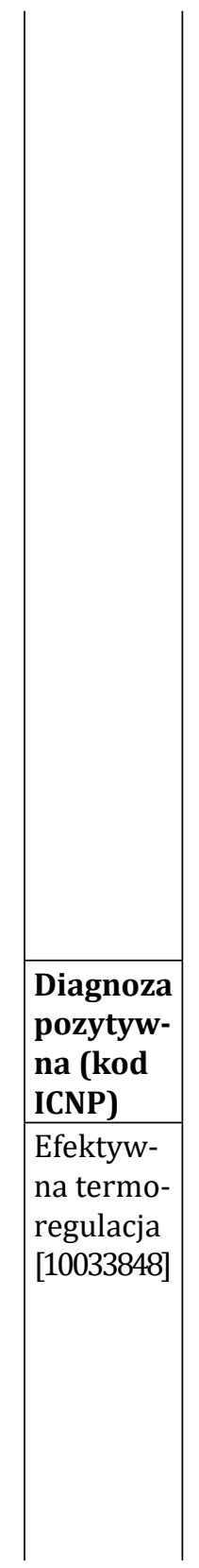




\begin{tabular}{|l|l|}
$\mid \begin{array}{l}\text { Asystowanie w higienie } \\
{[10030821]} \\
\text { Zarządzanie bezpie- } \\
\text { czeństwem środowiska } \\
{[10042507]} \\
\text { Ewaluacja odpowiedzi na } \\
\text { termoregulację [10007195] } \\
\text { Dokumentowanie } \\
{[10006173]}\end{array}$ & \\
\hline
\end{tabular}

\begin{tabular}{|c|c|c|c|c|}
\hline \begin{tabular}{l|} 
Problem \\
pielęgna- \\
cyjny
\end{tabular} & \begin{tabular}{|l|} 
Cel plano- \\
wanych \\
działań \\
pielę- \\
gniar- \\
skich
\end{tabular} & $\begin{array}{l}\text { Planowane } \\
\text { interwencje } \\
\text { pielęgniarskie }\end{array}$ & $\begin{array}{l}\text { Uzasadnienie plano- } \\
\text { wanej interwencji } \\
\text { pielęgniarskiej }\end{array}$ & \begin{tabular}{|l|} 
Ocena \\
realizo- \\
wanych \\
działań \\
pielę- \\
gniar- \\
skich \\
\end{tabular} \\
\hline $\begin{array}{l}\text { Możliwość } \\
\text { pogłębie- } \\
\text { nia stanu } \\
\text { niedoży- } \\
\text { wienia } \\
\text { z powodu } \\
\text { dalszej } \\
\text { utraty } \\
\text { masy } \\
\text { ciała. }\end{array}$ & \begin{tabular}{|l|} 
Stopniowa \\
poprawa \\
stanu od- \\
żywienia \\
dziecka, \\
wyrówna- \\
nie niedo- \\
boru masy \\
ciała.
\end{tabular} & $\begin{array}{l}\text { - Ocena statusu } \\
\text { odżywienia pa- } \\
\text { cjentki z zasto- } \\
\text { sowaniem BMI } \\
\text { i siatek centylo- } \\
\text { wych. } \\
\text { - Zastosowanie } \\
\text { diety bogatobiał- } \\
\text { kowej i wysoko- } \\
\text { energetycznej. } \\
\text { - Suplementacja } \\
\text { witamin i żelaza. } \\
\text { - Dokumentowa- } \\
\text { nie ilości spoży- } \\
\text { tych pokarmów } \\
\text { i płynów. } \\
\text { - Dbanie o es- } \\
\text { tetykę podania } \\
\text { posiłków. }\end{array}$ & $\begin{array}{l}\text { Ocena stanu odży- } \\
\text { wienia dziewczyny } \\
\text { pozwoli na ustalenie } \\
\text { jej zapotrzebowania } \\
\text { energetycznego } \\
\text { w celu zastosowania } \\
\text { leczenia } \\
\text { żywieniowego. } \\
\text { Dzienne spożycie } \\
\text { pokarmów o war- } \\
\text { tości energetycznej } \\
\text { o } 500 \text { kcal większej, } \\
\text { niż wynika to } \\
\text { z zapotrzebowania } \\
\text { kalorycznego } \\
\text { powoduje przyrost } \\
\text { masy ciała o około } \\
700 \text { g w ciągu } \\
\text { tygodnia. }\end{array}$ & $\begin{array}{l}\text { Stan } \\
\text { odżywie- } \\
\text { nia uległ } \\
\text { poprawie, } \\
\text { podjęte } \\
\text { działania } \\
\text { wymaga- } \\
\text { ją konty- } \\
\text { nuacji. }\end{array}$ \\
\hline
\end{tabular}




\begin{tabular}{|c|c|c|c|}
\hline & \begin{tabular}{|l} 
- Dbanie o es- \\
tetykę podania \\
posiłków. \\
- Zapewnienie \\
ciszy i spokoju \\
podczas spoży- \\
wania posiłków \\
- Ocena częstotli- \\
wości i charakte- \\
ru wypróżnień. \\
- Współpraca \\
z dietetykiem \\
w zakresie wdra- \\
żania dietotera- \\
pii.
\end{tabular} & \multirow[t]{3}{*}{$\begin{array}{l}\text { Dokumentowanie } \\
\text { ilości przyjętych po- } \\
\text { karmów oraz często- } \\
\text { tliwości i charakteru } \\
\text { wypróżnień umożliwi } \\
\text { ocenę skuteczności } \\
\text { podjętych działań, } \\
\text { a estetyczne podanie } \\
\text { posiłków zachęci pa- } \\
\text { cjentkę do ich spoży- } \\
\text { wania [5]. }\end{array}$} & \\
\hline $\begin{array}{l}\text { Diagnoza } \\
\text { negatyw- } \\
\text { na (kod } \\
\text { ICNP) } \\
\end{array}$ & $\begin{array}{l}\text { Interwencje } \\
\text { pielęgniarskie }\end{array}$ & & \begin{tabular}{|l} 
Diagnoza \\
pozytyw- \\
na (kod \\
ICNP) \\
\end{tabular} \\
\hline \begin{tabular}{|l} 
Niedo- \\
waga \\
{$[10027316]$}
\end{tabular} & $\begin{array}{l}\text { Planowanie opieki } \\
{[10035915]} \\
\text { Ocenianie apetytu } \\
{[10038901]} \\
\text { Ocenianie ryzyka zaburzo- } \\
\text { nego statusu odżywienia } \\
{[10040921]} \\
\text { Monitorowanie wagi } \\
{[10032121]} \\
\text { Monitorowanie odżywiania } \\
{[10036032]} \\
\text { Administrowanie suplemen- } \\
\text { tem diety [10037037] } \\
\text { Ocenianie statusu wypróż- } \\
\text { nienia [10036475] } \\
\text { Nauczanie o efektywnej } \\
\text { wadze [10033001] } \\
\text { Nauczanie o odżywianiu } \\
{[10024618]} \\
\text { Nauczanie o potrzebach die- } \\
\text { tetycznych [10046533] }\end{array}$ & & $\begin{array}{l}\text { Poprawa } \\
\text { statusu } \\
\text { odży- } \\
\text { wienia } \\
\text { [10035569] }\end{array}$ \\
\hline
\end{tabular}




\begin{tabular}{|l|l|}
$\mid \begin{array}{l}\text { Kierowanie do dietetyka } \\
{[10046788]} \\
\text { Ewaluacja odpowiedzi psy- } \\
\text { chospołecznej na instruowa- } \\
\text { nie dotyczące odżywiania } \\
{[1000711]} \\
\text { Ocenianie przestrzegania } \\
\text { diety [10044481] } \\
\text { Dokumentowanie } \\
{[10006173]}\end{array}$ & \\
\hline
\end{tabular}

\begin{tabular}{|c|c|c|c|c|}
\hline $\begin{array}{l}\text { Problem } \\
\text { pielęgna- } \\
\text { cyjny }\end{array}$ & $\begin{array}{l}\text { Cel plano- } \\
\text { wanych } \\
\text { działań } \\
\text { pielę- } \\
\text { gniar- } \\
\text { skich }\end{array}$ & $\begin{array}{l}\text { Planowane } \\
\text { interwencje } \\
\text { pielęgniarskie }\end{array}$ & $\begin{array}{l}\text { Uzasadnienie plano- } \\
\text { wanej interwencji } \\
\text { pielęgniarskiej }\end{array}$ & $\begin{array}{l}\text { Ocena } \\
\text { realizo- } \\
\text { wanych } \\
\text { działań } \\
\text { pielę- } \\
\text { gniar- } \\
\text { skich } \\
\end{array}$ \\
\hline $\begin{array}{l}\text { Deficyt } \\
\text { wiedzy } \\
\text { dziecka } \\
\text { oraz opie- } \\
\text { kunów } \\
\text { na temat } \\
\text { choroby. }\end{array}$ & \begin{tabular}{|l|} 
Pogłę- \\
bienie \\
wiedzy na \\
temat cho- \\
roby oraz \\
zalecane- \\
go postę- \\
powania \\
w okresie \\
remisji \\
i zaostrze- \\
nia.
\end{tabular} & $\begin{array}{l}\text { - Ocena stanu } \\
\text { wiedzy pacjentki } \\
\text { oraz jej rodziców } \\
\text { na temat cho- } \\
\text { roby. } \\
\text { - Zapoznanie } \\
\text { dziecka oraz ro- } \\
\text { dziców z istotą, } \\
\text { przyczynami } \\
\text { oraz możliwymi } \\
\text { następstwami } \\
\text { choroby. } \\
\text { - Edukacja } \\
\text { w zakresie } \\
\text { postępowania } \\
\text { w czasie remisji } \\
\text { i zaostrzenia } \\
\text { choroby. }\end{array}$ & $\begin{array}{l}\text { Ocena stanu wiedzy } \\
\text { pacjentki i jej } \\
\text { rodziców pozwoli } \\
\text { na przygotowanie } \\
\text { indywidualnego } \\
\text { planu } \\
\text { edukacyjnego. } \\
\text { Rodzice posiadając } \\
\text { niezbędną wiedzę } \\
\text { dotyczącą choroby, } \\
\text { sposobu jej leczenia } \\
\text { oraz możliwych } \\
\text { następstw } \\
\text { mogą aktywnie } \\
\text { i świadomie } \\
\text { uczestniczyć } \\
\text { w procesie leczenia } \\
\text { dziecka. }\end{array}$ & $\begin{array}{l}\text { Pacjent- } \\
\text { ka oraz } \\
\text { rodzice } \\
\text { posiadają } \\
\text { nie- } \\
\text { zbędną } \\
\text { wiedzę } \\
\text { na temat } \\
\text { choroby } \\
\text { Leśniow- } \\
\text { skiego- } \\
\text {-Crohna. }\end{array}$ \\
\hline
\end{tabular}




\begin{tabular}{|c|c|c|c|}
\hline & $\begin{array}{l}\text { - Dostosowanie } \\
\text { zakresu oraz } \\
\text { szczegółowości } \\
\text { informacji do po- } \\
\text { trzeb pacjentki } \\
\text { i jej opiekunów. } \\
\text { - Udzielanie od- } \\
\text { powiedzi na nur- } \\
\text { tujące pytania } \\
\text { oraz utrwalanie } \\
\text { wiedzy poprzez } \\
\text { powtarzanie. } \\
\text { - Dostarczenie } \\
\text { ulotek i broszur } \\
\text { na temat choro- } \\
\text { by Leśniowskie- } \\
\text { go-Crohna. } \\
\text { - Zapewnienie } \\
\text { wsparcia dietety- } \\
\text { ka i psychologa. } \\
\text { - Poinformowa- } \\
\text { nie o konieczno- } \\
\text { ści kontrolnych } \\
\text { wizyt lekarskich. } \\
\text { - Sprawdzenie } \\
\text { stopnia zrozu- } \\
\text { mienia przez } \\
\text { dziecko i rodzi- } \\
\text { ców dostarczo- } \\
\text { nych informacji. }\end{array}$ & $\begin{array}{l}\text { Dostarczone broszury } \\
\text { oraz umożliwienie } \\
\text { kontaktu z psycho- } \\
\text { logiem i dietetykiem } \\
\text { pozwalają na profesjo- } \\
\text { nalną opiekę wobec } \\
\text { dziecka. Sprawdze- } \\
\text { nie stopnia wiedzy } \\
\text { dziecka i rodziców po } \\
\text { zakończonej edukacji } \\
\text { wskaże na ewentualne } \\
\text { braki, które należy } \\
\text { utrwalić w celu za- } \\
\text { pewnienia dziecku jak } \\
\text { najlepszej opieki [5]. }\end{array}$ & \\
\hline $\begin{array}{l}\text { Diagnoza } \\
\text { negatyw- } \\
\text { na (kod } \\
\text { ICNP) }\end{array}$ & $\begin{array}{l}\text { Interwencje } \\
\text { pielęgniarskie }\end{array}$ & & $\begin{array}{l}\text { Diagnoza } \\
\text { pozytyw- } \\
\text { na (kod } \\
\text { ICNP) } \\
\end{array}$ \\
\hline $\begin{array}{l}\text { Brak } \\
\text { wiedzy } \\
\text { o chorobie } \\
{[10021994]}\end{array}$ & \begin{tabular}{|l} 
Planowanie opieki \\
{$[10035915]$} \\
Ocenianie wiedzy o chorobie \\
[10030639] \\
Nauczanie o chorobie \\
[10024116]
\end{tabular} & & $\begin{array}{l}\text { Ade- } \\
\text { kwatna } \\
\text { wiedza } \\
{[10027112]}\end{array}$ \\
\hline
\end{tabular}




\begin{tabular}{|c|}
\hline $\begin{array}{l}\text { Poradnictwo dla pacjenta } \\
\text { [10031062] } \\
\text { Ocenianie postawy wobec } \\
\text { reżimu terapii [10024205] } \\
\text { Promowanie przestrzegania } \\
\text { zaleceń dotyczących leków } \\
\text { [10038051] } \\
\text { Zapewnienie materiału in- } \\
\text { struktażowego [10024493] } \\
\text { Współdziałanie z dietety- } \\
\text { kiem [10040435] } \\
\text { Dokumentowanie } \\
\text { [10006173] }\end{array}$ \\
\hline
\end{tabular}

\begin{tabular}{|c|c|c|c|c|}
\hline $\begin{array}{l}\text { Problem } \\
\text { pielęgna- } \\
\text { cyjny }\end{array}$ & \begin{tabular}{|l|} 
Cel plano- \\
wanych \\
działań \\
pielę- \\
gniar- \\
skich
\end{tabular} & $\begin{array}{l}\text { Planowane } \\
\text { interwencje } \\
\text { pielęgniarskie }\end{array}$ & $\begin{array}{l}\text { Uzasadnienie plano- } \\
\text { wanej interwencji } \\
\text { pielęgniarskiej }\end{array}$ & $\begin{array}{l}\text { Ocena } \\
\text { realizo- } \\
\text { wanych } \\
\text { działań } \\
\text { pielę- } \\
\text { gniar- } \\
\text { skich }\end{array}$ \\
\hline $\begin{array}{l}\text { Obniżony } \\
\text { nastrój } \\
\text { spowo- } \\
\text { dowany } \\
\text { hospitali- } \\
\text { zacją. }\end{array}$ & $\begin{array}{l}\text { Poprawa } \\
\text { samopo- } \\
\text { czucia } \\
\text { pacjentki, } \\
\text { pomoc } \\
\text { w ada- } \\
\text { ptacji do } \\
\text { szpital- } \\
\text { nych wa- } \\
\text { runków. }\end{array}$ & $\begin{array}{l}\text { • Ocenianie sta- } \\
\text { nu psychicznego } \\
\text { pacjentki. } \\
\text { • Zapoznanie } \\
\text { pacjentki z topo- } \\
\text { grafią oddziału } \\
\text { oraz innymi } \\
\text { pacjentami. } \\
\text { • Wyjaśnianie } \\
\text { celowości oraz } \\
\text { przygotowanie } \\
\text { psychiczne do } \\
\text { wykonywanych } \\
\text { badań diagno- } \\
\text { stycznych. }\end{array}$ & $\begin{array}{l}\text { W celu obniżenia } \\
\text { lęku i niepokoju } \\
\text { pacjentki związanego } \\
\text { z hospitalizacją } \\
\text { należy zachęcać } \\
\text { ją do kontaktu } \\
\text { z rówieśnikami. } \\
\text { Wyjaśnianie celowości } \\
\text { oraz przebiegu } \\
\text { wykonywanych } \\
\text { badań pozwoli } \\
\text { na zrozumienie } \\
\text { konieczności } \\
\text { hospitalizacji oraz } \\
\text { wyzbycie się lęku. }\end{array}$ & $\begin{array}{l}\text { Nastrój } \\
\text { pacjentki } \\
\text { uległ po- } \\
\text { prawie }\end{array}$ \\
\hline
\end{tabular}




\begin{tabular}{|c|c|c|c|}
\hline & \begin{tabular}{|l|} 
- Zapewnie- \\
nie wsparcia \\
emocjonalnego \\
poprzez aktywne \\
słuchanie, goto- \\
wość do pomocy \\
oraz okazanie \\
życzliwości i zro- \\
zumienia. \\
- Zapewnienie \\
stałego kontaktu \\
z bliskimi. \\
- Umożliwienie \\
kontaktu z psy- \\
chologiem. \\
- Organizowanie \\
czasu wolnego. \\
\end{tabular} & \multirow[t]{3}{*}{$\begin{array}{l}\text { Zapewnienie rozrywki } \\
\text { w czasie czasu wol- } \\
\text { nego poprawi samo- } \\
\text { poczucie pacjentki, } \\
\text { a kontakt z psycholo- } \\
\text { giem pomoże zaak- } \\
\text { ceptować chorobę [5]. }\end{array}$} & \\
\hline \begin{tabular}{|l} 
Diagnoza \\
negatyw- \\
na (kod \\
ICNP)
\end{tabular} & $\begin{array}{l}\text { Interwencje } \\
\text { pielęgniarskie }\end{array}$ & & \begin{tabular}{|l} 
Diagnoza \\
pozytyw- \\
na (kod \\
ICNP) \\
\end{tabular} \\
\hline $\begin{array}{l}\text { Negatyw- } \\
\text { ny status } \\
\text { nastroju } \\
{[10047503]}\end{array}$ & $\begin{array}{l}\text { Planowanie opieki } \\
\text { [10035915] } \\
\text { Ocenianie nastroju } \\
\text { [10038938] } \\
\text { Ocenianie statusu psycholo- } \\
\text { gicznego [10030734] } \\
\text { Informowanie o hospitaliza- } \\
\text { cji [10042480] } \\
\text { Zapewnienie wsparcia emo- } \\
\text { cjonalnego [10027051] } \\
\text { Dodawanie otuchy } \\
\text { [10016480] } \\
\text { Promowanie wsparcia rodzi- } \\
\text { ny [10036078] } \\
\text { Kierowanie na terapię w gru- } \\
\text { pie wsparcia [10024558] } \\
\text { Kierowanie na terapię zaję- } \\
\text { ciową [10026415] }\end{array}$ & & $\begin{array}{l}\text { Poprawa } \\
\text { nastroju } \\
{[10050027]}\end{array}$ \\
\hline
\end{tabular}




\begin{tabular}{|l|l|}
$\begin{array}{l}\text { Nauczanie o terapii odwraca- } \\
\text { jącej uwagę [10043536] } \\
\text { Nauczanie o zarządzaniu } \\
\text { stresem [10038681] } \\
\text { Promowanie akcepta- } \\
\text { cji statusu zdrowotnego } \\
{[10037783]} \\
\text { Wspieranie statusu psycho- } \\
\text { logicznego [10019161] } \\
\text { Dokumentowanie } \\
{[10006173]}\end{array}$ & \\
\hline
\end{tabular}

\begin{tabular}{|c|c|c|c|c|}
\hline $\begin{array}{l}\text { Problem } \\
\text { pielęgna- } \\
\text { cyjny }\end{array}$ & $\begin{array}{l}\text { Cel plano- } \\
\text { wanych } \\
\text { działań } \\
\text { pielę- } \\
\text { gniar- } \\
\text { skich }\end{array}$ & $\begin{array}{l}\text { Planowane } \\
\text { interwencje } \\
\text { pielęgniarskie }\end{array}$ & $\begin{array}{l}\text { Uzasadnienie plano- } \\
\text { wanej interwencji } \\
\text { pielęgniarskiej }\end{array}$ & $\begin{array}{l}\text { Ocena } \\
\text { realizo- } \\
\text { wanych } \\
\text { działań } \\
\text { pielę- } \\
\text { gniar- } \\
\text { skich } \\
\end{array}$ \\
\hline $\begin{array}{l}\text { Ryzyko } \\
\text { wystą- } \\
\text { pienia } \\
\text { powikłań } \\
\text { z powodu } \\
\text { kaniulacji } \\
\text { żyły ob- } \\
\text { wodowej. }\end{array}$ & $\begin{array}{l}\text { Niedo- } \\
\text { puszcze- } \\
\text { nie do } \\
\text { powstania } \\
\text { powikłań. }\end{array}$ & $\begin{array}{l}\text { - Przestrzeganie } \\
\text { zasad aseptyki } \\
\text { i antyseptyki } \\
\text { podczas zakłada- } \\
\text { nia oraz pielę- } \\
\text { gnacji miejsca } \\
\text { wkłucia. } \\
\text { - Zabezpieczenie } \\
\text { przed samodziel- } \\
\text { nym usunięciem } \\
\text { wkłucia przez } \\
\text { pacjentkę po- } \\
\text { przez zastosowa- } \\
\text { nie bandaża. }\end{array}$ & $\begin{array}{l}\text { Przestrzeganie zasad } \\
\text { aseptyki i antyseptyki } \\
\text { zapobiega wystą- } \\
\text { pieniu zakażenia } \\
\text { wewnątrzszpitalnego } \\
\text { oraz powikłań lecze- } \\
\text { nia [5]. }\end{array}$ & $\begin{array}{l}\text { Nie } \\
\text { doszło do } \\
\text { wystą- } \\
\text { pienia } \\
\text { powikłań. }\end{array}$ \\
\hline
\end{tabular}




\begin{tabular}{|c|c|}
\hline & $\begin{array}{l}\text { - Systematycz- } \\
\text { na obserwacja } \\
\text { miejsca wkłu- } \\
\text { cia pod kątem } \\
\text { wystąpienia za- } \\
\text { palenia (obrzęk, } \\
\text { zaczerwienienie, } \\
\text { bolesność). } \\
\text { - Zmiana opa- } \\
\text { trunku raz na } \\
\text { dobę lub częściej } \\
\text { w razie potrzeby } \\
\text { (zabrudzenie, } \\
\text { odklejenie się). } \\
\text { - Założenie i pro- } \\
\text { wadzenie karty } \\
\text { wkłucia obwodo- } \\
\text { wego. } \\
\text { • Usunięcie ka- } \\
\text { niuli po } 72 \mathrm{~h} \text { lub } \\
\text { zmiana miejsca } \\
\text { wkłucia po upły- } \\
\text { wie tego czasu. }\end{array}$ \\
\hline $\begin{array}{l}\text { Diagnoza } \\
\text { negatyw- } \\
\text { na (kod } \\
\text { ICNP) }\end{array}$ & $\begin{array}{l}\text { Interwencje } \\
\text { pielęgniarskie }\end{array}$ \\
\hline $\begin{array}{l}\text { Ryzyko } \\
\text { kompli- } \\
\text { kacji zwią- } \\
\text { zanych } \\
\text { z opieką } \\
\text { zdro- } \\
\text { wotną } \\
\text { [10041296] }\end{array}$ & $\begin{array}{l}\text { Planowanie opieki } \\
\text { [10035915] } \\
\text { Wstawianie urządzenia } \\
\text { do dostępu naczyniowego } \\
\text { [10041784] } \\
\text { Używanie techniki aseptycz- } \\
\text { nej [10041784] } \\
\text { Ocenianie oznak i sympto- } \\
\text { mów infekcji [10044182] } \\
\text { Utrzymywanie drożności } \\
\text { systemu żylnego [10036577] } \\
\text { Zastosowanie bandaża ela- } \\
\text { stycznego [10030472] } \\
\text { Dokumentowanie } \\
\text { [10006173] }\end{array}$ \\
\hline
\end{tabular}

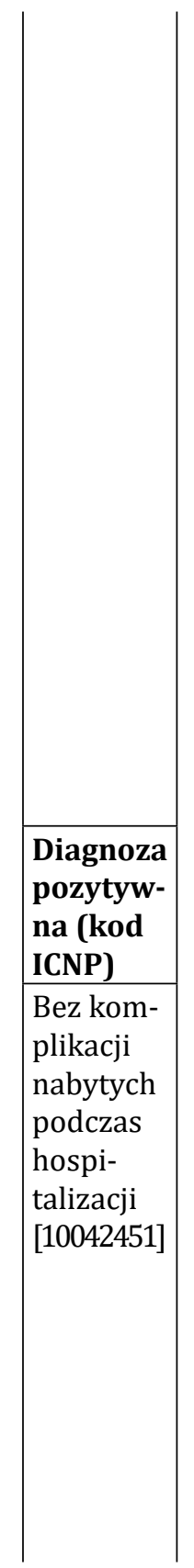




\section{Dyskusja}

Dziewczynka ze względu na swój obecny stan zdrowia nie jest w stanie w pełni samodzielnie funkcjonować. Ponadto pacjentka nie radzi sobie psychicznie z chorobą oraz koniecznością ciągłego kontrolowania swojego stanu zdrowia. Jest zaniepokojona hospitalizacją. Zarówno dziewczynka, jak i jej rodzice nie mają wystarczającej wiedzy na temat choroby Leśniowskiego - Crohna oraz zasadach postępowania zarówno w stanie remisji, jak i zaostrzenia choroby. Biorąc pod uwagę obecny stan pacjentki oraz analizując dokumentację medyczną i występujące u chorej problemy, wdrożono poniższe modele opieki.

Model opieki według Dorothei Orem, który opiera się na teorii deficytu samoopieki, wyróżniając trzy systemy pielęgnowania:

- System całkowicie kompensacyjny

- System częściowo kompensacyjny

- System wspierająco - uczący

W opiece nad pacjentką zastosowano dwa z nich: model wspierająco - uczący w stosunku do dziecka i rodziców oraz model częściowo - kompensacyjny w stosunku do dziecka. Niewystarczająca wiedza oraz brak motywacji wymaga pomocy pielęgniarki, która pełni rolę edukatora oraz wspiera i motywuje dziewczynę w podejmowaniu decyzji na rzecz zdrowia [6].

Kolejnym modelem zastosowanym $\mathrm{w}$ opiece nad pacjentką jest model Callisty Roy. Zakłada on pomoc pacjentowi w przystosowaniu się do nowej sytuacji w jego życiu. Pielęgniarka ma za zadanie kształtować pozytywne nastawienie do życia, zdrowia i własnej osoby oraz rozwijać u pacjenta możliwość radzenia sobie w sytuacjach trudnych. Istotne jest również wspomaganie rozwoju poprzez nakłanianie osoby chorej do prób samodzielnego rozwiązywania problemów.

Ostatnim modelem wdrożonym do opieki nad dziewczyną jest model pielęgnowania według Virginii Henderson oparty na teorii potrzeb człowieka. Kluczowe jest zaspokojenie podstawowych potrzeb życiowych: odpoczynek, sen, wydalanie czy też utrzymanie prawidłowej temperatury ciała. Konieczne jest więc zastosowanie pomocy pie- 
lęgniarskiej w celu jak najszybszego uzyskania przez pacjentkę samodzielności [7].

\section{Wnioski}

Po rozpoznaniu sytuacji klinicznej pacjentki stwierdzono stan zaostrzenia choroby Leśniowskiego-Crohna. W związku z powyższym wdrożono zindywidualizowany plan opieki oraz wysnuto następujące wnioski:

1. U młodocianej pacjentki $w$ trakcie hospitalizacji rozpoznano podwyższoną temperaturę ciała, co predysponowało do wystąpienia powikłań. Kolejnym problemem charakterystycznym przy zaostrzeniu choroby Leśniowskiego-Crohna była zaburzona równowaga wodno - elektrolitowa spowodowana występowaniem licznych wodnistych stolców. Zaobserwowano także dyskomfort pacjentki spowodowany silnym bólem brzucha oraz obniżony nastrój spowodowany hospitalizacją i złym stanem zdrowia.

2. Pielęgniarka, mając pod opieką dziecko z zaostrzeniem choroby Leśniowskiego - Crohna ma za zadanie:

- zaplanować zindywidualizowaną opiekę nad pacjentem biorąc pod uwagę występujące u niego problemy

- podawać leki zgodnie z pisemnym zleceniem lekarskim

- systematycznie monitorować podstawowe parametry życiowe

- rozpoznawać deficyty wiedzy i uzupełniać je zgodnie z kompetencjami

- wspierać dziecko psychicznie i udzielać odpowiedzi na nurtujące je pytania

- wyjaśniać celowość hospitalizacji oraz konieczność wykonywania badań diagnostycznych

- obserwować postępy medyczne w celu oceny skuteczności podjętych działań $[8,9]$. 


\section{Bibliografia/Bibliography:}

1. Wiśniewska - Jarosińska M., Wichan P., Chojnacki J. Choroba Leśniowskiego - Crohna u osób młodych. Terapia. 2010:6:69-72.

2. Łodyga M., Witanowska A., Pawlik M., Rydzewska G. Choroba Leśniowskiego Crohna. Dąbrowski A. (Red.), Gastroenterologia. Medical Tribune Polska, Warszawa 2019:341-356.

3. https://www.icn.ch/what-we-do/projects/ehealth/icnp-browser

4. Kilańska D. Międzynarodowa klasyfikacja praktyki pielęgniarskiej ICNP $®$ w praktyce pielęgniarskiej. Wydawnictwo Lekarskie PZWL, Warszawa 2014.

5. Kózka M., Płaszewska - Żywko L. Diagnozy i interwencje pielęgniarskie. Wydawnictwo Lekarskie PZWL, Warszawa 2008:51,52,72,81,144,145,22 $7,228,250,252$.

6. Cepuch G. Model Dorothei Orem w opiece nad dzieckiem w chorobach ostrych i zagrażających życiu. Cepuch G., Perek M. (Red.), Modele opieki pielęgniarskiej nad dzieckiem z chorobą ostrą i zagrażającą życiu. Wydawnictwo Lekarskie PZWL, Warszawa 2012:39 - 42.

7. Lenartowicz H., Kózka M. Metodologia badań w pielęgniarstwie. Podręcznik dla studiów medycznych. Wydawnictwo Lekarskie PZWL, Warszawa 2011:52-57,86 - 109.

8. Golik M., Kurek M., Poteralka A. i wsp. Working Group Guidelines on the nursing roles in caring for patients with Crohn's disease and ulcerative colitis in Poland. Przegląd Gastroenterologiczny. 2014:9 (4):179 - 193.

9. Kiełbasa J. Opieka pielęgniarska nad pacjentem z chorobą Leśniowskiego - Crohna. Opis przypadku. Klimaszewska K., Baranowska A., Krajewska Kułak E. (Red.), Współczesne wyzwania w ochronie zdrowia. Uniwersytet Medyczny w Białymstoku. Wydział Nauk o Zdrowiu, Białystok 2018:661 -673 . 